\title{
Sustainability of Agricultural Microfinance Institution: Empirical Evidence from Yogyakarta, Indonesia
}

\author{
RetnoSetijowati, Masyhuri, Lestari Rahayu, Jamhari ${ }^{1}$ \\ ${ }^{I}$ Faculty of Agriculture, Gadjah Mada University of Yogyakarta, Indonesia
}

\begin{abstract}
Providing sustainable financial services for agriculture continues to be a challenge in spite of billions of dollars having been spent in subsidies to strengthen financial institutions to serve the sector.This study identified factors that influence the sustainability of Agricultural Microfinance Institution (MFI-A) in Yogyakarta, Indonesia. The research applied survey approach by conducting interview towards 111 managers of MFI-Ain Special District of Yogyakarta. The sustainability of the institutions were measure by self-help funding. The factors influencing the sustainability of MFI-Ain Rural Agribusiness Development were analyzed using multiple linear regression analysis technique. The results of the study showed that: the factors which influenced the self-help funding to support the sustainability of MFI-Awere, the credit lending for offarm activity credit screening, monitoring and accompaniment, incentive and sanction mechanism.
\end{abstract}

Keywords: Agricultural Microfinance Institution, sustainability

\section{Introduction}

It has been a long time since Indonesian Government tries to increase the living standard of farmers which is the biggest portion of the structure of Indonesian society. A lot of programs have been implemented to help the farmers in achieving higher position in Indonesian economy. Various aid schemes have also been carried out, starting from subsidized production facilities, direct capital assistance, farm credit, and others. Those aids have not met the expected result. They even cause farmers be more dependent and unable to work on their own farming business (Mushero 2008).

In reformation era, exactly in 2008, Government had issued a Rural Agribusiness Development program which was a poverty reduction program based on community empowerment. The Rural Agribusiness Development program aimed to reduce the poverty and unemployment through the growth and development of agribusiness activity in the rural areas based on their potentials, by empowering farmer organizations and rural economy in supporting the development of agribusiness activity as well as increasing the function of economic institutions to become a network or financial institution partners in the context of access to capital. Agricultural Microfinance Institution (MFI-A) is a basic unit and smallest co-operative credit institutions in Indonesia. It works on the grassroots level (Ministry of Agriculture 2010).

In Yogyakarta District, there were 339 Agricultural Cooperative (87\%) which had formed MFI-A (2008 and 2010). However, in the implementation, there were several problems in its first years of performance, such as: troubled funding by indication of the refund from late members as well as undeveloped business of the members, late asset development of the MFI-A, low technical ability from the administer, unpreparedness in autonomous business growth, overlong cash flow from the Agricultural Cooperative which the member of farmers could receive the Rural Agribusiness Development fund (Indonesia Central Bank 2013). Those conditions indicated the problems towards the sustainability of the MFI-A .

The MFI-A can continue due to the fact that the MFI-A as rural economic institution is, much needed in presence. This institution is the part of farmer empowerment program which is different from previous credit aid program for farmers. The MFI-A is the farmer group business in empowering the farmers from financial aspect related to the other empowerment aspects (production, management of yield, marketing, management of farming facilities, and so on). The failure is not only caused by the design of the program but also by its implementation.

Observed from the lending problem, the low effectivity of the MFI-A can be caused by unclear information regarding the credit worthiness of farming outside the variety of limited agriculture loans (e.g. most of the loans to the agricultural sector, food sector, or even activities outside the agricultural sector), no follow-up if the non performing loan happens that is no firm sanction for members whose loans were in trouble, so it can influence other members not to pay in installment loans (Indonesia Central Bank, 2013). On the side of user of the fund, the members in general are low-income households which are "too poor" to do saving (Asyraf 2008). The accumulation of fund by the MFI-A is the most important aspect for the sustainability of institution. The bigger the accumulated fund in the institution from the members, the bigger the chance for the institution in producing the fund for its members is. Moreover, the expectation for the sustainability of the institution in managing the fund will get bigger as well. The MFI-A segment that is poor society who is familiar with 
subsidies (capital and interest level from the Government) causes low independence. Many microfinance institutions are initially built for social interests instead of financial purposes.

MFI-A still has lack points either in control mechanism and general, administration and management support. As new grown company, the MFI-A must take care of lots of things to be an independent organization. In the future, the management of MFI-A must be able to overcome the low cash flow problem as well as the affectivity and the efficiency of management.

The sustainability of Rural Agribusiness Development program are important since it is one of the strategic steps to solve the financing problems of micro farmers and farm workers who has been difficult to get financial services through formal financial institutions. The sustainability of MFI-A is decided by the capacity of farmers, the MFI-A manager and Agricultural Cooperative as well as the external support. By the increasing of strategic plan of the Agricultural Cooperative as as a farmer institutional executor of Rural Agribusiness Development program, it is expected that farmers be able to increase their living quality through efforts to develop the abilities and skills of human resources (farmers), to increase the scale of operations and create efficiencies in its activities which at times will intensify its productivity. Based on the description above, the research generally aims to analyze the sustainability of MFI-A of Agricultural Cooperative in Rural Agribusiness Development in Special District of Yogyakarta and the factors influencing it..

\section{Research Methods}

Research location in Indonesia, Special Region of Yogyakarta.In 2008, the Indonesian Government had developed farmers' institution through Gapoktan which aimed at empowering the farmers. Gapoktan is an affiliation of several groups of farmers that conducts agribusiness activities based on collectivity and partnership principles so that increased production rate and income for its member and others farmers are achieved. In its very essence, MFI-A and Gapoktan are not merely a subsidiary program, but more to one of empowerment program. It is a program of institutional arrangement made for the purpose of strengthening farmers' position on the chain of agricultural commodities value. It manages input market, production efficiency, post-harvest management, marketing and distribution. In addition, there is an autonomous Agribusiness Microfinance Institutions (MFI-A) operated within the farmer group institution (Gapoktan) system to manage the capital supply of its member. Thus, as explained previously, it is expected that the lending activity which is purposed for strengthening the agriculture activities, from head to toe, will eventually resulted on significantly increased MFI-A's sustainability.

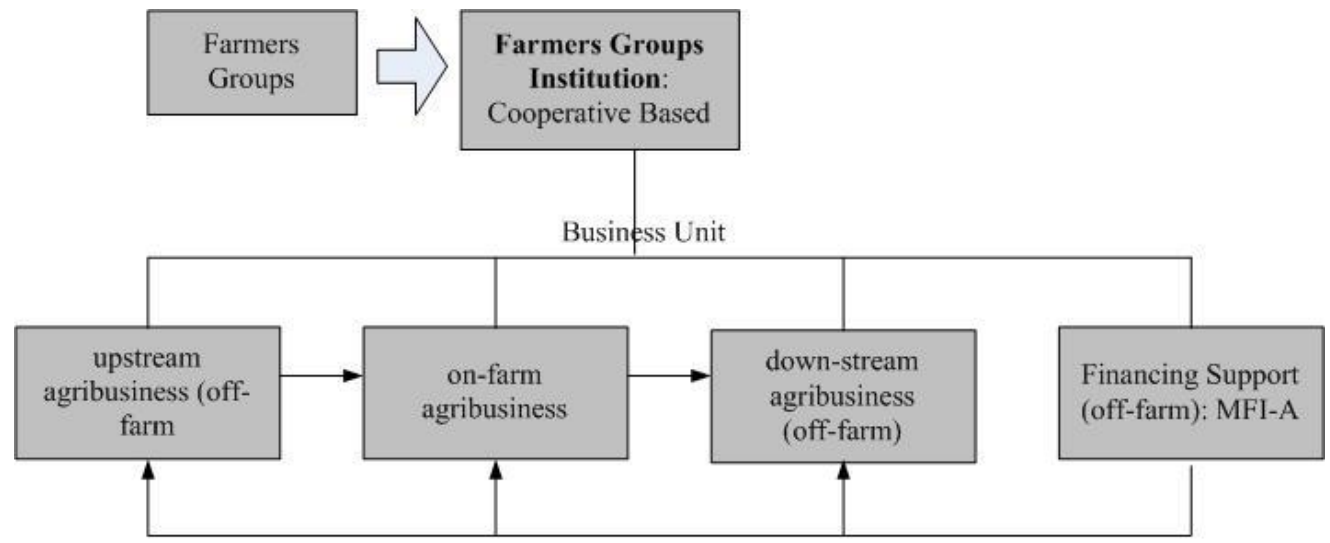

Figure 1. MFI-A and Gapoktan Activity

Source: Ministry of Agriculture, 2010

The researcher used survey approach by conducting interview to 11 managers of MFI-A in Special District of Yogyakarta which obtained MFI-A program. Agriculture sector of Yogyakarta has a very important role in forming gross regional domestic product based on current price in 2015, that of 13.91 percent. Research conducted in 4 regency: Kulon Progo, Sleman, Bantul and Gunung Kidul.

The sustainability of MFI-A was measured by capital accumulation minus subsidies. Furthermore, Ledgerwood (1999) states that financial sustainability illustrates the capacity to cover all the required costs and institution's ability to keep operating without continuous subsidies (including soft loan and grants) and loss. Moreover, Armendariz de Aghion and Morduch (2005) explain that support received from outside party is only for the sake of micro-financial program at the initial stage of the development, and will eventually vanished as the economic scale grows, which in turn left MFI-A to operate by itself. 
Sustainability of Agricultural Microfinance Institution: Empirical Evidence from Yogyakarta,

Table 1. Variable and Measurement

\begin{tabular}{|c|c|c|c|}
\hline Variable & Code & & Measurement \\
\hline \multicolumn{4}{|l|}{ Dependent Variable } \\
\hline Sustainable of MFI-A & SUS & $=$ & Logaritma Natural of capital - subsidies (Mlllion Rp) \\
\hline Lending & LEND & $=$ & $\begin{array}{l}\text { total lending to member (cumulative, } 3=>150 \text { juta, } 2=100-150 \\
\text { juta } 1=<100 \text { juta) }\end{array}$ \\
\hline Lending for poor farmers & POOR & $=$ & total lending to poor farmers $(3=>80 \%, 2=50 \%-80 \%, 1=<50 \%)$ \\
\hline Lending for off farm activity & OFFFARM & $=$ & $\begin{array}{l}\text { total lending to post-harvesting management, marketing and } \\
\text { distribution (off farm) }(3=>80 \%, 2=50 \%-80 \%, 1=<50 \%)\end{array}$ \\
\hline Credit Screening & $\mathrm{CS}$ & $=$ & $3=$ discussed in the finance committee, $2=$ rarely, $1=$ no available \\
\hline Monitoring and Accompaniment & MA & $=$ & $3=$ available, $2=$ rarely, $1=$ no available \\
\hline Age & AGE & $=$ & years \\
\hline $\begin{array}{l}\text { Infrastructure (computers, office, } \\
\text { vehicle operation, savings deposit slips, } \\
\text { withdrawal slips deposits, passbook } \\
\text { members, loan application form, etc.) }\end{array}$ & INFR & $=$ & $\begin{array}{l}3=\text { available and support, } 2=\text { available and no support, } 1=\text { no } \\
\text { support }\end{array}$ \\
\hline Region & REGION & $=$ & Dummy \\
\hline
\end{tabular}

The factors which influenced the sustainability of MFI-A of Agricultural Cooperative in Rural Agribusiness Development were analyzed using multiple linear regression analysis technique with following equation.

$\mathrm{SUS}=\beta_{0}+\beta_{1} \mathrm{ONFARM}+\beta_{2} \mathrm{POOR}+\beta_{5} \mathrm{OFFARM}+\beta_{6} \mathrm{CS}+\beta_{7} \mathrm{MON}+\beta_{8} \mathrm{SANK}+\beta_{9} \mathrm{MAN}+\beta_{10} \mathrm{AGE}+\beta_{11} \mathrm{INFR}+$ $\beta_{12}$ REGION $+\varepsilon$

Where: $\alpha, \beta, \gamma=$ intercept and slope, $\varepsilon=$ error. To assess the accuracy of the sample regression function in assessing the actual value can be measured from its goodness of fit. Statistically the goodness of fit can be measured from the statistical value of $\mathrm{F}$ and coefficient determination. The coefficient of determination $\left(\mathrm{R}^{2}\right)$ is used to determine the percentage of dependent variable change caused by the independent variable. $F$ test is the significance testing of the equations used to determine how influence the independent variables on dependent variable (Y). The p-value is the probability of rejecting the null hypothesis given that it is true. The significance level is 1\% (very significant), 5\% (significant) and 10\% (moderate significant). The p-value is less than the significance level, then an investigator may conclude that the observed effect actually reflects the characteristics of the population rather than just sampling error (Cowles and Davis 1982).

\subsection{Sustainability of MFI-A}

\section{Results And Discussion}

According Table 2 can be seen that most MFI-A has self-supporting fund (principal savings, obligatory savings and special savings) less than Rp 5000000 (49.55\%). MFI-A of the research which possesses selfsupporting fund in the range of Rp. 5000000 - Rp. 10000000 is mounted to $28.83 \%$ while only $21.62 \%$ have mounted their self-supporting fund above Rp. 10000 000. Low savings can be caused due to several is due to the following reasons as follows: First, commonly, farmers have limited income so then they found it difficult to spare some of their money to do the savings. Second, some farmers consider debt relief as other assistance, which is a granted for free, and possesses limited knowledge regarding the role of savings to the development of their MFI-A which, in fact, principal savings, obligatory savings, special savings and voluntary savings is a potential for self-dependent MFI-A. Moreover, savings can also guarantee their right to acquire debt from. There are $74.77 \%$ of the population of MFI-A (United Farmers' Groups) possesses approximately Rp. 100000 000 - Rp. 150000000 of capital while only 0.90\% of the population possesses less than Rp. 100000000 of capital (or decreasing capital compared to initial capital given by PUAP). Meanwhile, this research analyzes the $24.32 \%$, as the sample of the research, of the population which possesses more than Rp. 150,000,000 of capital. Principal savings, obligatory savings and voluntary savings are sources of potential funding for MFI-A apart from the profit/cost of services/payment of administrative fees by the borrower. The amount of obligatory savings agreed by the members in which every new member pay at in their admission to the institution, is equal.. Principal saving is deposited at the time of registration of a member, wich means that this deposit is the capital of the newly joining member. While obligatory savings shall be paid each month in which the amount is 
Sustainability of Agricultural Microfinance Institution: Empirical Evidence from Yogyakarta,

also equal between each member in accordance to the agreement made in the council. The average size of the amount of principal saving for each Gapoktan differs, with some Gapoktan obliged their member to pay Rp. 10 000 for the principal saving and Rp. 5000 as the monthly paid obligatory saving.

Table 2. Sustainability of MFI-A

\begin{tabular}{|l|c|c|c|}
\hline \multicolumn{2}{|l|}{ Effectivity and Sustainability } & Total (n) & Percent (\%) \\
\hline 1. & Total Asset & & \\
\hline & $\square>150$ million Rp & 27 & $24.32 \%$ \\
\hline & $\square 100-150$ million Rp & 83 & $74.77 \%$ \\
\hline & $\square<100$ million Rp & 1 & $0.90 \%$ \\
\hline & Total & 111 & $100.00 \%$ \\
\hline 2. & Self-help fund & & \\
\hline & $\square>10$ million Rp & 24 & $21.62 \%$ \\
\hline & $\square 5-10$ million Rp & 32 & $28.83 \%$ \\
\hline & $\square<5$ million Rp & 55 & $10.55 \%$ \\
\hline & Total & 111 & \\
\hline 3. & Non Performing Loans & & $35.14 \%$ \\
\hline & $\square<5 \%$ & 39 & $30.63 \%$ \\
\hline & $\square 5-10 \%$ & 34 & $34.23 \%$ \\
\hline & $\square>10 \%$ & 38 & $100.00 \%$ \\
\hline & Total & 111 & \\
\hline
\end{tabular}

Source: From questioner data, 2016

The non performing loan was also a problem for some MFI-A. The inability to pay for the installment loans of some members caused the capital unable to rotate. Based on the interviews with some of MFI-A managers, the causes why the administrators had not enforced the rules which had been agreed upon the unsmooth return were: 1) stalled effort, 2) following others who did not pay, 3) considering that the fund was an aid or a grant, 4) being used for other urgent needs, 5) the distrust of Agricultural Cooperative' and the MFI-A ' administrators.

\subsection{Characteristic of Lending Activity Segmen}

According Table 3 can be seen that majority (71.17\%) of MFI-A in Yogyakarta a cumulative distribution (total lending to members) amounted to Rp. 100000000 - Rp. 150000000 . MFI-A had a cumulative distribution (total lending to members) < Rp. 100000000 was $14.41 \%$, while MFI-A had a cumulative distribution (total lending to members)> Rp. 150000000 was $14.41 \%$. MFI-A in Yogyakarta which allocate its fund for agricultural development to the amount percentage of $>80 \%$ is $34.23 \%$, while the majority of $60.36 \%$ allocate its fund ranging from $50 \%$ to $80 \%$. In addition, the rest of $5.41 \%$ allocate its fund for agricultural issues no more than $50 \%$ which means that fund allocating is directed mostly to non-agricultural issues. MFI-A in Yogyakarta reach the percentage of $32.43 \%$ in allocating more than $80 \%$ of the fund for poor farmers, indicated by the possession by BPJS PBI and raskin, which further elaborated by the statements of MFI-A managers recorded in the interviews that almost all lending fund for members are for those of poor farmers. Moreover, $50.45 \%$ has the allocation percentage of $50 \%-80 \%$ to poor farmers while the rest $17.12 \%$ spend less than $50 \%$ of the fund for poor farmers.

Table 3. Lending Activity

\begin{tabular}{|l|l|l|l|}
\hline \multicolumn{2}{|l|}{ Lending Activity } & Total (n) & Percent (\%) \\
\hline 1. & Total Lending & & \\
\hline & $\square>150$ million Rp & 16 & $14.41 \%$ \\
\hline & $\square 100-150$ million Rp & 79 & $71.17 \%$ \\
\hline & $\square<100$ million Rp & 16 & $14.41 \%$ \\
\hline & Total & 111 & $100.00 \%$ \\
\hline 2. & Lending to agricultural activity & & \\
\hline & $\square>80 \%$ to agricultural activity & 38 & $34.23 \%$ \\
\hline & $\square 50-80 \%$ to agricultural activity & 67 & $60.36 \%$ \\
\hline & $\square<50 \%$ to agricultural activity & 6 & $5.41 \%$ \\
\hline & Total & 111 & $100.00 \%$ \\
\hline 3. & Lending to poor farmers & & \\
\hline & $\square>80 \%$ to poor farmers & 36 & $32.43 \%$ \\
\hline & $\square 50-80 \%$ to poor farmers & 56 & $50.45 \%$ \\
\hline & $\square<50 \%$ to poor farmers & 19 & $17.12 \%$ \\
\hline & Total & 111 & $100.00 \%$ \\
\hline 4. & Lending to on farm and off farm Activity & \\
\hline & $\square \quad$ on-farm agribusiness only & 77 & $69.37 \%$ \\
\hline & $\square \quad$ on farm and down-stream agribusiness*) & 34 & $30.63 \%$ \\
\hline & Total & 111 & $100.00 \%$ \\
\hline
\end{tabular}

Note: *) post-harvesting management, marketing and distribution (off farm)

Source: From questioner data, 2016 
Most of MFI-A (61.26\%) allocate the fund mostly on food business segment (cultivation), postharvesting management, marketing and distribution (off farm) (21.62\%), livestock (9.01\%), horticulture cultivation $(7.21 \%)$, and plantation cultivation less than one percent. The majority of the Gapoktan use the PUAP funding only for on-farm agribusiness (69.37\%), and on farm and down-stream agribusiness (30.63\%). The allocation proportion is mainly due to members' traditional occupation as farmers.

\subsection{Credit Management and Governance}

The Guideline of MFI-A PUAP 2014 states that every funding or lending making should be equipped with calculation and analysis of feasibility. According Table 4 can be seen that most respondents $(67.57 \%)$ agree that the mechanism of lending control should be taken into account for each meeting of funding commission. Moreover, they also agree that every funding or lending agreement should passed Funding Committee Assembly which consisted of at least three people from three elements, namely the manager, the board, and the supervisor. On the other hand, $31.53 \%$ of the respondent state that it is discussed in less occasion compared the former.

Table 4. Credit Management and Governance

\begin{tabular}{|l|l|l|l|}
\hline Control Mechanism of Credit & Total (n) & Percent (\%) \\
\hline 1. & Credit Screening & & \\
\hline & $\square$ discussed in the finance committee & 75 & $67.57 \%$ \\
\hline & $\square$ rarely & 35 & $31.53 \%$ \\
\hline & $\square$ no available & 1 & $0.90 \%$ \\
\hline $2 . \quad$ Monitoring and Accompaniment & 111 & $100.00 \%$ \\
\hline & $\square$ available & & $68.47 \%$ \\
\hline & $\square$ rarely & 76 & $31.53 \%$ \\
\hline & $\square$ no available & 35 & $0.00 \%$ \\
\hline & Total & 0 & $100.00 \%$ \\
\hline 3. & Incentives and sanctions mechanism & 111 & $29.73 \%$ \\
\hline & $\square$ available & 33 & $32.43 \%$ \\
\hline & $\square$ rarely & 36 & $37.84 \%$ \\
\hline & $\square$ no available & 42 & $100.00 \%$ \\
\hline & Total & 111 & \\
\hline
\end{tabular}

Source: From questioner data, 2016

Furthermore, further development on members' business is necessary considering the low educational background of the farmers which eventually results on incapability on money management. There are $68.47 \%$ of the respondent recognize the development program on money management composed by PMT (Associate Farmer Management and local farming supervisors), and also received numerous visits from farming supervisors in conducting their business. On the other hand, $31.53 \%$ of the respondent state that the development program rarely takes place. Moreover, the rarity of development program is due to several causes as follows: 1) the money is misused to non-agricultural issues, 2) irrelevant knowledge of the farming supervisors to the farmers' needs, 3) the farming supervisors suffered from illness and no replacement yet, and 4) the farming supervisors moved and no replacement yet.

There are $29.73 \%$ of the respondent state that there is a reward/punishment mechanism for good and bad credit. The reward mechanism takes into action if the borrower pay the debt more than expected so then Gapoktan through the MFI-A grants the borrower an increased amount of lending for future or certain presents, while the punishment mechanism takes into action if the borrower infringed the agreement and failed to pay the installments three months consecutively so then the chief of the farming group visits the borrower in private. Yet, if the borrower still failed to pay, then he/she will be losing the right to make any lending in the future. However, the punishment mechanism do not take into action if the borrower were suffering from natural disaster, pest, illness or/and harvest failure. On the other hand, $32.43 \%$ of the respondent state that such mechanism is rarely taken into action, and even $37.84 \%$ state that there is no such mechanism in their knowledge.

Meanwhile, the voluntary saving is one kind of savings that requires no exact amount of money from the members to be stored, and, in addition, also differs in regulation and application of different Gapoktan. $85.59 \%$ of the sample of the research has half of its member owning voluntary saving and $9.01 \%$ has all of the members owning voluntary saving. Moreover, $5.41 \%$ focuses only in providing debt and has no member owning voluntary saving due to the nature of voluntary saving which is a saving for members who have spare funds.

\subsection{Control Variable}

The challenges for MFI-A managers for the development of MFI-A, specifically, and Gapoktan, generally, are heavily complex. First, the development of agricultural environment, environmental technology and agricultural market environment are highly dynamic which such changes require adept MFI-A managers 
Sustainability of Agricultural Microfinance Institution: Empirical Evidence from Yogyakarta,

who can properly address to changes in the environment. Second, many stakeholders, or conflict of interests, in the development of the agricultural sector, poor society and rural developing in which MFI-A managers are required to respond to any opportunity within the environment of the stakeholders. Third, the very unique characteristics MFI-A segment. Farmers and rural communities have characteristics of social and cultural environments significantly different from financial and other banking institutions. A variety of demanding challenges MFI-A managers to respond the opportunities and threats of the external environment, understand financial management, MFI-A operations management, networking management, as well as understanding the social and cultural characteristics, traditions and local wisdom. Unfortunately, the research found that the educational backgrounds of the managers are not sufficient. 84.68\% of MFI-A managers are highschooleducated, $5.41 \%$ are junior highschool-educated, and only $9.91 \%$ have experienced higher education.

According Table 5 can be seen that majority of the respondent $(53.15 \%)$ state that MFI-A has equipped with sufficient supporting facility to keep up the works while $29.73 \%$ of the respondents state the opposite. The office of MFI-A and Gapoktan are still provide by the chief of Gapoktan as well as the other production means. Some Gapoktan have their own computers, yet still lack of other supporting facility such as operational vehicle, saving withdrawal paper, members' savings books, lending application form, cash book, etc in which considered as essential to the MFI-A regarding its significance to the well-being of the Gapoktan and LKM-A, and as a social cohesive device between members and stakeholders such as accounting matters, cash flow and yearly report, and proposal application to the stakeholders.

The sample of the research are those who have received PUAD funding in 2007-2010 with the proportion of $24.32 \%$ have received funding from 2009 (seven years), 36.94\% have received funding from 2008 (eight years), $16.22 \%$ have received funding from 2007 (nine years) and $22.52 \%$ have received funding from 2010 (six years).

\subsection{The Result of the Regression Test}

Summary results of regression testing the factors that influence the sustainability of MFI-A presented in Table 5. The result of regression obtained F-test value whose each of significant on the fault level was $1 \%$. These results also showed together or simultaneous factors that existed in the model significantly affected the sustainability of MFI-A . The result of regression equation model obtained Adjusted R-squared value of 0.414 or $41.4 \%$ which reflected that every free variable was able to explain variation of changes that was an increase or decrease in the dependent variable at $41.4 \%$, while the rest of it, that was $58.6 \%$, was influenced by other variables which were not involved in this research. The result of regression obtained Jarque-Bera value (p) of $0.951(>0,10)$, Breusch-Godfrey Serial Correlation LM Test $(\mathrm{p})$ of $0.515(>0,10)$ and Heteroskedasticity Test: Breusch-Pagan-Godfrey (p) of $0.806(>0,10)$ which reflected that model did not have serious problems toward normality, autocorrelation and heterocedasticity test. This research found 3 (three) factors from 5 (five) tested factors that significantly influence the sustainability of MFI-A. Those factors were credit lending to postharvest management, marketing and distribution (off farm) activity, credit screening (SC), monitoring and accompaniment (MA). While 2 (two) other factors (lending to on farm activity (ON FARM) and insentive and sanction mechanisme (SANK)) did not significantly influence the sustainability of MFI-A .

The credit lending to post-harvest management, marketing and distribution (off farm) activity have positively affects the sustainability of MFI-A $(p=0.002<1 \%)$. The regression coefficient (slope) $(\beta=0.444)$ means that the raising in credit lending is 1 level and followed by the increasing number of sustainability of MFI-A for $0.444 \%$. In the contrary, credit lending is decreased by 1 level will be followed by the decrease of the sustainability of MFI-A to $0.444 \%$ and the variables must be constant.

The credit screening have positively affects the sustainability of MFI-A $(p=0.047<5 \%)$. The regression coefficient (slope) $(\beta=0.368)$ means that the raising in credit screening is one level and followed by the increasing number of sustainability of MFI-A for $0.368 \%$. In the contrary, credit screening is decreased by one level will be followed by the decrease of the sustainability of MFI-A to $0.368 \%$ and the variables must be constant. 
Sustainability of Agricultural Microfinance Institution: Empirical Evidence from Yogyakarta,

Table 5. Regression Test Summary

\begin{tabular}{|c|c|c|}
\hline & \multicolumn{2}{|c|}{$\begin{array}{l}\text { Dependent Variable: } \\
\text { Sustainability }\end{array}$} \\
\hline & $\beta$ & $p$ \\
\hline Constant & -5.700 & 0.000 \\
\hline \multicolumn{3}{|l|}{ Lending Activity } \\
\hline ONFARM & -0.073 & 0.582 \\
\hline OFFFARM & 0.444 & $\begin{array}{ll}* * *) & 0.002\end{array}$ \\
\hline \multicolumn{3}{|l|}{ Governance } \\
\hline $\mathrm{CS}$ & 0.368 & 0.047 \\
\hline MON & 0.502 & ***) $\quad 0.000$ \\
\hline SANK & -0.074 & 0.395 \\
\hline \multicolumn{3}{|l|}{ Control Variable } \\
\hline MAN & 0.466 & $* * *)$ \\
\hline $\mathrm{AGE}$ & 0.125 & *) $\quad 0.081$ \\
\hline INFR & -0.064 & 0.534 \\
\hline REGION & 0.098 & 0.112 \\
\hline R-squared & 0.462 & \\
\hline Adjusted R-squared & 0.414 & \\
\hline F-statistic & 9.624 & \\
\hline Prob(F-statistic) & 0.000 & \\
\hline Durbin-Watson stat & 2.177 & \\
\hline Jarque-Bera (p) & 0.951 & \\
\hline $\begin{array}{l}\text { Breusch-Godfrey Serial Correlation LM } \\
\text { Test (p) }\end{array}$ & 0.515 & \\
\hline $\begin{array}{l}\text { Heteroskedasticity Test: Breusch-Pagan- } \\
\text { Godfrey (p) }\end{array}$ & 0.806 & \\
\hline
\end{tabular}

Description: $* * *)$ level of significancy $=1 \%, * *$ ) level of significancy $=5 \%, *$ ) level of significancy $=10 \%$, Source: From questioner data, 2016

The monitoring and accompaniment have positively affects the sustainability of MFI-A ( $\mathrm{p}=0.000$ $<1 \%)$. The regression coefficient (slope) $(\beta=0.502)$ means that the raising in monitoring and accompaniment is one level and followed by the increasing number of sustainability of MFI-A for $0.502 \%$. In the contrary, monitoring and accompaniment is decreased by one level will be followed by the decrease of the sustainability of MFI-A to $0.502 \%$ and the variables must be constant.

This research found the factors which influenced the sustainability of MFI-A were credit lending to post-harvest management, marketing and distribution (off farm) activity, credit screening, monitoring and accompaniment. While two other factors did not significantly influence the sustainability of MFI-A . Those factors are lending to on farm activity and insentive and sanction mechanisme.

The total of credit lending for crop agriculture activities did not significantly influence the sustainability of MFIA . Those was caused by the average length of narrow working land of the farmers so the increasing of the capital would not able to increase the income of farmers in crop agriculture activities. The other problem which could be caused by the risk of agricultural environment and the risk of market towards the crop agriculture activity. The total of credit lending for post-harvest management, marketing and distribution (off farm) activity have significantly influenced the sustainability of MFI-A. This thing shows that the post-harvest management, marketing and distribution (off farm) activity is such a potential that it can increase the farmers' income and it has lower risk comparing to the crop agriculture activity.

The credit screening mechanisme through the discussion of distribution of fund by means of funding committee significantly influenced the sustainability of MFI-A. The credit screening mechanisme through the discussion of distribution of fund by means of funding committee could direct and filter the distribution of fund for potential activities which could result in income for the members and the MFI-A .

A monitoring and accompaniment mechanism of fostering the use of loan fund have significantly affect the sustainability of MFI-A. PUAP program will be directed at empowering and strengthening MFI-A as an exit strategy that aims to provide a solution for farmers to more easily access and obtain financial services in order to improve their agribusiness. Supporting components in an effort to realize this exit strategy is the role of mentoring in the field conducted by PMT. PMT act as a facilitator in building the institutional capacity of Gapoktan as farmers, develop agribusiness committed by farmers in rural areas as well as the growth and empowerment of MFI-A.

The incentive and sanction mechanism did not significantly influence the sustainability of MFI-A. The incentive and sanction mechanism did not significantly influence the sustainability of MFI-A because this mechanism was more for the enforcement of loan payment. Therefore, the incentive and sanction mechanism did not have negative and significant impact on the level of troubled funding. This result of research supports the previous research conducted by Amoah et al. (2012), Anuchachart (2011), Aveh (2013) who found that various activities which reduced the risk such as screening and monitoring mechanism were the most important factor towards the success of microfinance institution in the rural areas. 
This research also found the two control variable have positively and significantly on sustainability of MFI-A. It showed that managerial education in increasing the ability in managing the MFI-A resources (management capacity and entrepreneurship) to signify the asset accumulation of MFI-A got higher. However, higher managerial education could not increase the self-reliance of members through the member's activities in saving (for example, the compulsory saving, the principal, and the voluntarily saving). It could be explained by Asyraf finding (2008) that was most of the farmers had low income and were not accustomed to saving especially those poor farmers. Even though the managers were not able to increase their awareness, the increasing of farmers' ability could not be achieved in a short period of time.

The infrastructure of MFI-A gave positive and significant influence on the sustainability of MFI-A . This is because the infrastructure of this institution (computer, office, operational vehicles, savings deposit slip, savings withdrawal slip, member saving book, loan application form, cashbook, and others) has role in supporting the operational activity of the MFI-A, as in records and bookkeeping, coordination, communication and sharing of information, so they indirectly support the performance of the institution. The infrastructure did not significantly influence the level of troubled funding because it is only for supporting the performance of the MFI-A. The infrastructure did not have significant influence towards the level of troubled funding because was only used to support the supporting facilities in fund screening activity, the monitoring of fund usage and the enforcement of payment. Therefore, its influence was not significant.

\section{Conclusion}

The factors which influenced the sustainability of MFI-A were credit lending to post-harvest management, marketing and distribution (off farm) activity, credit screening, monitoring and accompaniment. This result provides implications of the influence of market segments of MFI-A towards the sustainability of Agricultural Cooperative in Rural Agribusiness Development in Special District of Yogyakarta. The use of credit outside the agricultural activity is more effective than the increasing of MFI-A income.

The result of the research also provides development implication of MFI-A of Agricultural Cooperative which are integrated among the agricultural activity and its supporters, the agricultural activities from upstream to downstream chain. This research was conducted by the survey approach so it was hard to insert the factor of macro economy influence and the regulations. The previous researches were able to insert some of those factors by collecting the secondary data existing in the Agency for Agricultural Technology or other instances for data from several years before.

\section{Acknowledgements}

The authors thank the BPTP (Assessment Institute for Agricultural Technology; Yogyakarta, Indonesia) and PMT (Associate Farmer Management and local farming supervisors)who helpful this study and reviews on an earlier version of this manuscript. Thanks also to the staffs of Agriculture Program, Gadjah Mada University of Yogyakarta, Indonesia.

\section{References}

[1] Ahmed, S.F., Malik, A. Q., Credit Risk Management and Loan Performance: Empirical Investigation of Micro Finance Banks of Pakistan. International Journal of Economics and Financial Issues, 5(2), 2015, 574-579.

[2] Amoah, B.K, , Charles, R.O., Bennet, B., Obenewaa, A.L, Nusenu. A. Risk Management and Its Impact Profitability ini Microfinance Institutions. Joumal SSM 2 (1), 2012, 36-47

[3] Anuchachart, Measuring Performance of Bank of Agricultural and Agricultural Cooperatives (BAAC), Thailand; Relationships Between Institutional Goals And Future Trend. Independent Final Report presented to Professor SUZUKI Yasushi Of Ritsumeikan Asia Pacific University, 2011, r-cube.ritsumei.ac.jp/bitstream/10367/3691/1/52109616.pdf

[4] Asyraf, W.D., Banking for the poor: the role of banking in microfinance initiatives", Humanomics , 24(1), 2008, 49 - 66

[5] Aveh. An Evaluation of How Institutional Characteristics, Agency Cost, Business Strategy and Governance affect Sustainability of Microfinance Institutions in Ghana. International Journal of Advances in Management and Economics 2(1), 2013, 47-60

[6] Banerjee A, Besley T, Guinnane T.. Thy neighbour's keeper. The design of a credit cooperative with theory and a test. Quarterly Journal of Economics 109 (2), 1994, 491-515

[7] Cowles, M. and Davis, C., On the Origins of the .05 Level of Statistical Significance. American Psychologist 37(5), 1982, 553-558

[8] Hansmann, H., Ownership of the Firm, Journal of Law, Economics, and Organization, 4(2), 1988, $267-304$.

[9] Huime, R.B.M., M. Meuwissen, J.B. Hardacker and J.R. Anderson, Risk and risk management in agriculture: an overview and empirical results, Intemational Joumal of Risk Assessment and Management, 1, 2000, 125-136.

[10] Indonesia Central Bank, Effectiveness and Sustainability in Agribusiness Financing Program in Poverty Reduction Efforts in DIY through the Institute of Agribusiness Microdinance Institution (MFI-A ). Cooperation between the Indonesia Central Bank and Gadjah Mada University, Yogyakarta, 2013.

[11] Ministry of Agriculture, Pokja Pengendali PNPM Mandiri (PNPM Mandiri). Jakarta : Sekretariat Pokja Pengendali PNPM Mandiri, 2010

[12] Mushero, H. "Pemberdayaan Petani Melalui Gabungan Kelompok Tani (GAPOKTAN)". Accessed on October 19, 2012 eprints.uny.ac.id/7741/

[13] Yopi, S., Jangkung, H.M, and Lestari, R.., Efisiensi Lembaga Keuangan Mikro Agribisnis Gabungan Kelompok Tani dalam Pengembangan Usaha Agribisnis Perdesaan : Studi Kasus di Kabupaten Bantul Tahun 2012. Jumal Agro Ekonomi 30 (2), $129-144$ 
[14] Wakaisuka-Isingoma, J. , Aduda, J., Wainaina, G. and Mwangi, C.I., Corporate governance, firm characteristics, external environment and performance of financial institutions in Uganda: A review of literature. Cogent Business \& Management 3, 2016, 1261526

[15] Zeller M, Meyer RL., The Triangle of Microfinance-Financial Sustainability, Outreach and Impact. John Hopkins University Press, Baltimore and London, 2002. 